\title{
A CHECKLIST OF SOIL-DWELLING POLYCHAETOUS ANNELIDS FROM SOME INDIAN MANGROVE HABITATS
}

\author{
R. Sunil Kumar
}

Department of Zoology, Catholicate College, Pathanamthitta, Kerala 689645, India. Email: rskumar66@yahoo.com

\begin{abstract}
Polychaetes form an important component of the food chain in mangrove ecosystems especially from fisheries point of view. For the present study monthly survey in three mangroves in Cochin was carried out for two years. A checklist of soil dwelling polychaetous annelids was prepared with the help of literature on polychaetes specific to mangrove ecosystems of India. Sixty-two species of 35 genera have been reported from three Indian mangroves (Sunderbans, Bombay and Cochin) out of which those coming under Errantia group (44 species) were dominant when comparred to Sedentaria group (18 species). Among the 15 families identified, the species diversity of Neridae and Eunicidae were found to be high.
\end{abstract}

\section{Keywords}

Mangroves, polychaetous annelids, checklist, Sunderbans, Bombay, Cochin

\section{Introduction}

Mangrove ecosystem is one of the most productive ecosystem of tropical and subtropical regions of the world. Of the various associated organisms of mangrove swamps -- both epifauna and infauna -- polychaetes form an important component of food chain operating there, especially from the fisheries point of view. In India, epifaunal organisms including crustaceans and molluscs of mangroves, both from west and east coasts, have been enlisted (Molur \& Walker, 1998). Even though studies on species composition, distribution and abundance of polychaete fauna have been made on certain selected areas of Indian mangroves in Sunderbans, Cochin and Bombay, no attempt has been taken to enlist them in connection with biodiversity conservation.

Recent estimates show that India has a mangrove cover of approximately 6,36,000ha, on the basis of a landsat data of 1987.

Received on 3 April 2000

Accepted on 17 December 2000
Almost 80 per cent of the mangrove forests are found along the east coast while the west coast only has 20 per cent cover (Untawale, 1998). As far as the present study is concerned, only a few literature is available on polychaete fauna to assess the diversity of species from Indian mangroves. These works were carried out in Sunderbans (Nandi \& Choudhury, 1983; Misra \& Choudhury, 1985), Bombay (Padmakumar, 1984) and Cochin (Sunil Kumar \& Antony, 1994a,b; Sunil Kumar, 1995). This indicates the lack of information on polychaetes from other mangrove areas of India, mainly from Gujarat, Goa, Karnataka, Lakshadweep Islands, Tamil Nadu, Andhra Pradesh, Orissa and Andaman and Nicobar Islands. More work such as survey and monitoring needs to be done on these mangrove areas from biodiversity conservation point of view.

\section{Study area and Methods}

The population density of polychaetes in Cochin mangroves based on my study is presented in Figure 1. For this, monthly survey was carried out in the three mangrove areas (stations 1, 2 and 3 ) for two years from low, mid and high tide levels (LTL, MTL and HTL) of the intertidal area. Samples were collected by using a box cover from the soil where roots of mangrove flora and detritus of mangrove origin were present. Polychaetes were collected after sieving the samples through a $0.5 \mathrm{~mm}$ mesh sieve. They were counted and monthly mean values were taken for each tidal level. Population density was expressed in $0.1 \mathrm{~m}^{2}$ area. Monthly variations of density in each tidal level of the three stations are shown in Figure 1.

\section{Results}

The study revealed the fact that among the various benthic organisms, polychaete fauna form an important component of Cochin mangroves. The rich diversity of polychaete fauna found there indicates the favourable ecological niche prevailing in the mangrove ecosystem (Sunil Kumar \& Antony, 1994b).

Literature of the studies on polychaetes specific to mangrove ecosystem of India were selected for preparing this checklist of soil dwelling polychaetous annelids of Indian mangrove habitat. 
In the present assessment it can be inferred that over 62 species of 35 genera have so far been reported from some Indian mangroves -- Cochin, Sunderabans and Bombay (Table 1). Polychaetes coming under Errantia group (44 species), more active in burrowing, dominate when compared to the Sedentaria group (18 species). Among the 15 families identified in Indian mangroves, the species diversity of Nereidae and Eunicidae families were found to be higher. The members of the genera Nereis, Lumbriconereis and Glycera were dominant among the polychaete species. The species namely Nereis glandicincta, Branchiocapitella singularis, Marphysa gravelyi, Pista indica and Eunice tubifex recorded from the Cochin mangroves are found to be new records to Indo-Pacific mangrove ecosystem (Sunil Kumar, 1999).

More studies on polychaete fauna, especially on taxonomic basis, needs to be made in the soil habitat of mangroves in various localities of India, which would give a complete picture on the distribution of polychaetes.

\section{References}

Misra, A. and A. Choudhury (1985). Polychaetous annelids from the mangrove swamps of Sunderbans, India, In: Bhosale, L.J. (ed.) Proceedings on the National Symposium on Biological Utilization and Conservation of Mangroves, pp. 448-452.

Molur S. and S. Walker (1998). Report of the "Conservation Assessment and Management Plan workshop for Indian mangrove ecosystems" (BCPP Endangered Species Project). Zoo Outreach Organsiation/ CBSG India, Coimbatore,

Nandi, S. and A. Choudhury (1983). Qualitative studies on the benthic macrofauna of Sagar Island, Intertidal zones, Sunderbans, India. Mahasagar 16(3): 409-414.

Padmakumar, K.G. (1984). Ecology of a mangrove swamp near-Juhu Beach, Bombay with reference to sewage pollution. Ph.D. Thesis, University of Bombay. Sunil Kumar, R and A. Antony (1994a). Preliminary studies on the polychaete fauna of the mangrove areas of Cochin. In: Ravi Kumar, R. (ed.) Proceedings of the Sixth Kerala Science Congress, pp. 74-77.

Sunil Kumar, R. and A.Antony (1994b). Impact of environmental parameters on polychaetous annelids in the mangrove swamps of Cochin, South west coast of India. Indian Journal of Marine Science 23: 137-142.

Sunil Kumar, R. (1995). Animal-sediment interaction with respect to the distribution pattern of polychaetous annelids in the mangrove ecosystem of Cochin backwaters. Journal of Zoological Society of Kerala 5: 43-48.

Sunil Kumar, R. (1999). New record of five annelids (Class: Polychaeta) from the mangrove habitat of IndoPacific region. Journal of Marine Biological Association
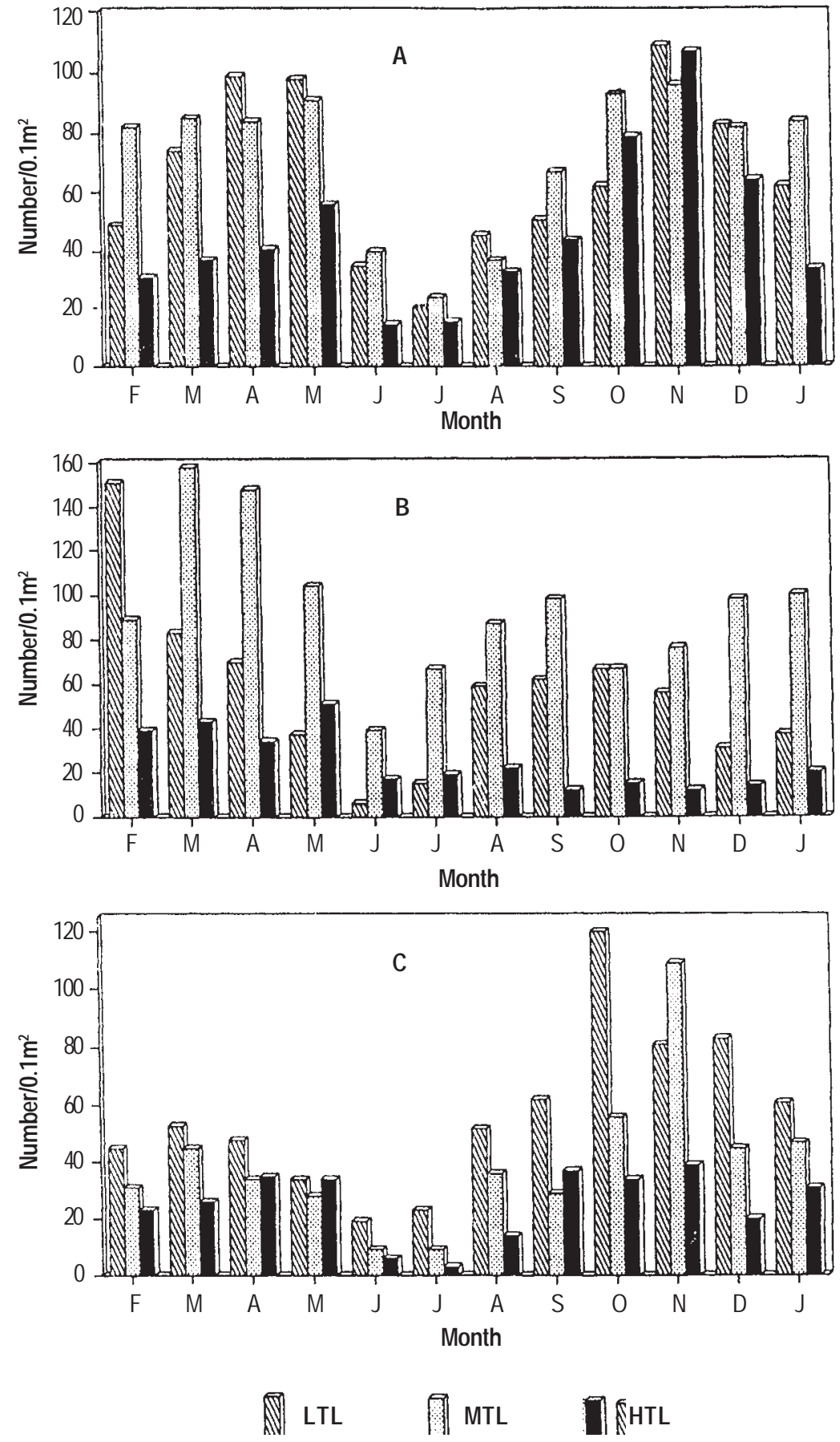

Figure 1. Monthly mean values of polychaeta in relation to tidal levels at (A) Station 1; (B) Station 2; (C) Station 3

of India 41.

Untawale, A.G. (1998). Management of mangroves for energy needs. In: Anon. An Anthology of Indian Mangroves. Environmental Information System Centre of Advanced Study in Marine Biology, Annamalai University, pp. 52-56. 
Table 1. List of soil-dwelling polychaetes of some Indian mangroves

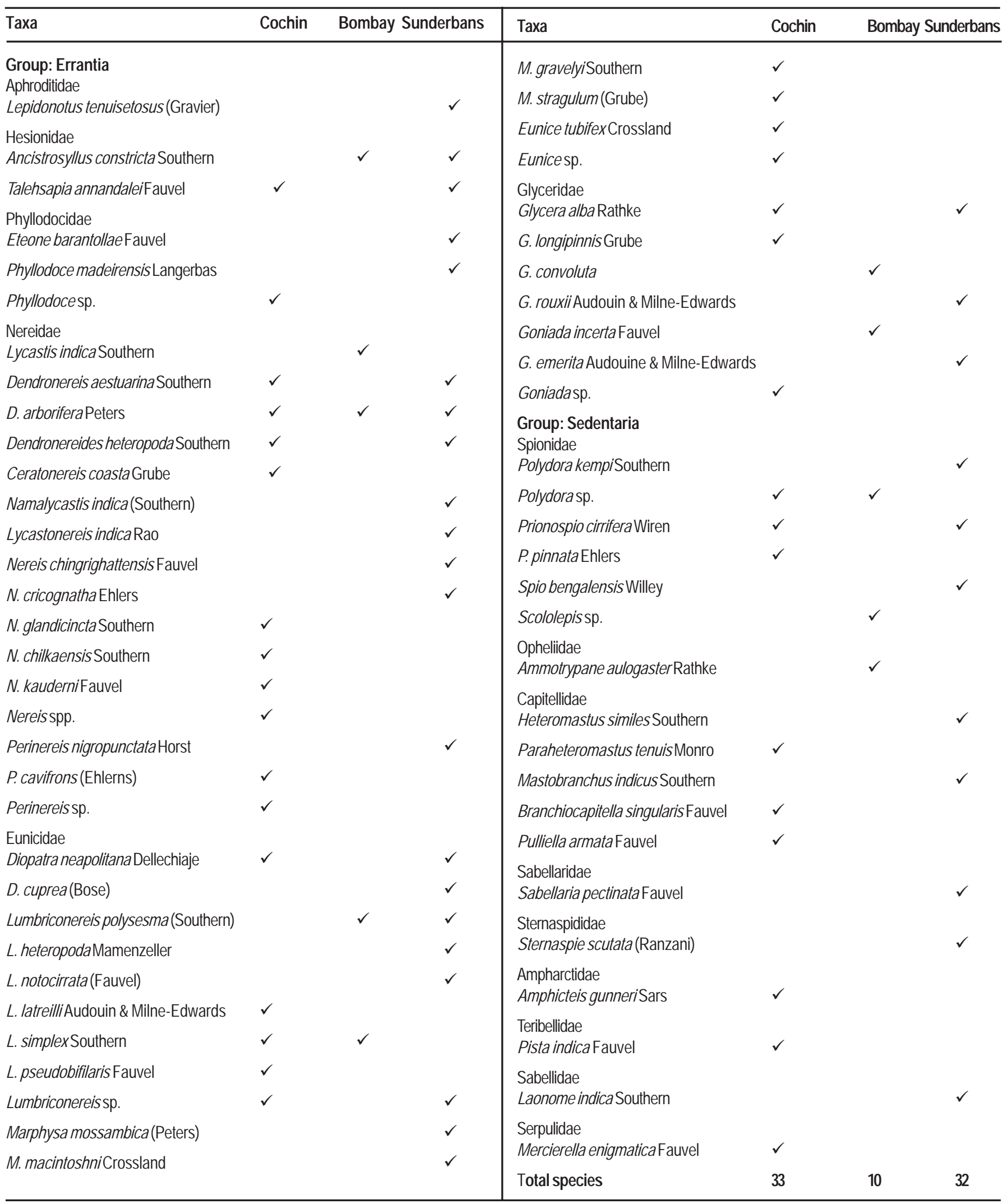

